\title{
EFFECT OF COPPER OXYCHLORIDE, ELEMENTAL SULPHUR, AND RHIZOBIUM INOCULATION ON ROOT ROT DISEASE, NODULATION, AND GROWTH OF FABA BEAN PLANTS

\author{
Al-Kahal, A. A. ${ }^{1}$; H.M. Mansoor ${ }^{2}$ and E.A. Ashmawy ${ }^{2}$ \\ ${ }^{1}$ Soils, Water and Environ. Res. Institute, Agric. Res. Center, Giza, Egypt \\ ${ }^{2}$ Plant Pathology Res. Inst. ARC, Giza, Egypt
}

\begin{abstract}
A pot experiment was conducted to evaluate the effect of applying copper oxychloride at a rate of $100 \mathrm{ppm}$ and elemental sulphur at a rate of $100 \mathrm{~kg} / \mathrm{feddan}$ as a fungicides and/or Rhizobium inoculation for controlling faba bean root rot disease caused by Rhizoctonia solani and Fusarium solani. Nodulation, growth and Npercentage of faba bean shoots were also evaluated. The results were as follows:

In soil infected with Rhizoctonia application of the fungicides alone or in combination with Rhizobium inoculation increased seedling emergence compared to that infected with Rhizoctonia only. Infection of faba bean with Fusarium showed lower emergence percentage compared to soil infected with Rhizoctonai. Copper oxychloride or sulphur had negative effect on seedling emergence for controlling faba bean root rot caused by Fusarium solani. The most effective treatment in reducing infection \% caused by Rhizoctonia solani was recorded in soil treated with copper oxychloride or elemental sulphur.

Rhizobium Inoculation in soil infected with Rhizoctonia solani or Fusarium solani decreased significantly infection percentage. Application of copper oxychloride or combination of Rhizobium and copper oxychloride had no effect on the infection \% with Fusarium solani. In faba bean plants infected with Rhizoctonia solani, application of copper oxychloride or sulphur with or without Rhizobium inoculation had no effect on nodulation status.

Concerning to the effect of Fusarium solani on nodulation status, the results indicated that infection with Fusarium had an inhibitory effect on the nodulation of faba bean even in the presence of the fungicides. There was a significant increase in dry weight of shoots in soil infected with Rhizoctonia solani and treated with copper oxychloride compared to control plants. Rhizobium inoculation also increased significantly dry weight of faba bean shoots. Application of the fungicides had no effect on dry weight of shoots in soil infected with Fusarium solani.
\end{abstract}

Keywords: Copper oxychloride, Sulphur, Rhizobium, Faba bean, Root rot disease

\section{INTRODUCTION}

Root rot diseases are a major limiting factor in legume production. The disease depress seedling germination and cause emergence damping off, resulting in low yield. Root diseases of faba bean (Vicia faba L.) can rarely be ascribed to a single distinctive pathogen but is usually a complex pathological condition. Salt (1983) reported several soil-borne fungi as the causal organisms (Rhizoctonia solani, Fusarium oxysporum, Fusarium solani, Pythium spp, Sclerotinia spp.). Effective control strategies against root rot fungal pathogens have not been fully developed. Chemical seed treatment 
before planting is a common practice to prevent seed and seedling rots, damping off and other fungal diseases. However, problems arise when the chemical seed treatments are to be used in conjunction with Rhizobia inoculants. In some cases, the applied seed fungicide may fail to protect against the intended pathogen or suppresses the effectiveness of the Rhizobium inoculants. Sulphur has been known and used as a pesticide since very early times, and has been registered for pesticide use in the United States since the 1929s (U.S.EPA, 1991). Currently, sulphur is registered for use as a fungicide and insecticide on several crops.

Copper-containing compounds have a long history of successful use as agricultural fungicides and are now being recognized as very hazardous pollutants. Copper salts are widely used to control bacterial and fungal diseases in agriculture (Mapper et al., 1984). The beneficial effects of inoculating legumes with Rhizobium is well known and widely used in agriculture for crop improvement due to their ability to fix nitrogen (Roughley et al., 1983). However, the recommended rates of the fungicides applied are often inhibitory to root nodule bacteria. For the last three decades, studies on the compatibility of Rhizobium strains with fungicides have been controversial. Application of Captan, Pentachloronitrobenze (Curley and Burton, 1975) and Apron (Revellin et al., 1993) on soybean (Glycine max) reduced the viability of Bradyrhizobium japonicum by 18,75 and $61 \%$, respectively, after one hour exposure.

Therefore, the objectives of this study were to investigate: (1) the influence of soil treatment with recommended rates of sulphur and copper oxychloride as a fungicides on the incidence of root rot disease of faba bean plants caused by Rhizoctonia solani, and Fusarium solani. (2) the effect of these fungicides on nodulation status and growth of faba bean plants and $\mathrm{N}$ percentage in presence of the fungal pathogens.

\section{MATERIALS AND METHODS}

A Pot experiment was conducted at Agricultural Research Center, Giza, to study the effect of elemental $S$ and Copper oxychloride as a fungicides on root rot disease, nodulation status and growth of faba bean plants.

\section{Sources of seeds, fungicides and soil}

1- Elemental sulphur (S) 100\% and Copper oxychloride (Caprile 50\%) were obtained from Plant Pathology Res. Inst., ARC, Giza, Egypt

2- Rhizobium inoculum (Rhizobium leguminosarum) was kindly obtained from BNF Unit, Microbiology Dept., Soils, Water, and Environment Res. Inst. ARC, Giza, Egypt.

3- Faba bean seeds (Vicea faba) Giza 3 cultivar were kindly provided by Field Crops Res. Inst., ARC, Giza, Egypt

4- Soil sample was collected from ARC farm, Giza. The mechanical and chemical analyses of the experimental soil are presented in Table (1).

Through this study two fungal isolates from diseased faba bean plants were used, one isolate of Rhizoctonia and one isolate of Fusarium. The isolates proved their pathogenic capability in the pathogenicity test. 


\section{Preparation of fungal inoculum}

The fungal inocula were grown on sterilized barley grains medium for 12 days at $25 \pm 1^{\circ} \mathrm{C}$. Each pathogen was added to the soil at a rate of $3 \%$ $(w / w)$. The infested soil was watered daily for one week to enhance growth and distribution of the fungal inoculum.

The experiment divided into two groups: The first one infested with Rhizoctonia solani and included six treatments with three replicates and as follows: (1) Control (2) Soil treated with elemental sulphur at a rate of $100 \mathrm{~kg} / \mathrm{feddan}$ (3) Soil treated with copper oxychloride at a rate of $100 \mathrm{ppm}$ (4) faba bean seeds inoculated with commercial Rhizobium inoculants (Rhizobium leguminosarum) (5) Seeds inoculated with Rhizobium and fertilized with starter dose of $\mathrm{N}$ fertilizer and the elemental $\mathrm{S}$ was mixed with the soil. (6) Seeds inoculated with Rhizobium and fertilized with starter dose of $\mathrm{N}$ fertilizer and the fungicide was mixed with the soil. The second included the same treatments but the soil was infested with Fusarium solani. Rhizobium inoculation was done before sowing. Seeds were coated with peat inocula using Arabic gum $16 \%$ as an adhesive agent. The pots were arranged in a complete randomized design. Four seeds were sown in each pot and plants were watered as needed.

Table (1): Mechanical and chemical properties of the soil

\begin{tabular}{|l|c|}
\hline Properties & Value \\
\hline Coarse sand (\%) & 7.59 \\
\hline Fine Sand (\%) & 23.00 \\
\hline Silt (\%) & 33.60 \\
\hline Clay (\%) & 35.81 \\
\hline Textural class & Clay loam \\
\hline pH (1:5 soil suspension) & 7.67 \\
\hline E.C.dSm ${ }^{-1} 1: 5$ (soil : water) & 0.76 \\
\hline O.C. $(\%)$ & 0.68 \\
\hline O.M. $(\%)$ & 1.18 \\
\hline Total N (\%) & 0.42 \\
\hline & \\
\hline $\mathrm{Ca}^{++}$ & 0.77 \\
\hline $\mathrm{Mg}^{++}$ & 3.06 \\
\hline $\mathrm{Na}^{+}$ & 0.79 \\
\hline $\mathrm{K}^{+}$ & 0.79 \\
\hline & \\
\hline $\mathrm{CO}^{-}$ & Soluble cations (meql \\
\hline $\mathrm{HCO}_{3}^{-1}$ & -- \\
\hline
\end{tabular}

Recommended dose of Calcium superphosphate $\left(15.5 \% \mathrm{P}_{2} \mathrm{O}_{5}\right)$ was mixed with the soil at a rate of $100 \mathrm{~kg} / \mathrm{fed}$. Ammonium nitrate $(33.5 \% \mathrm{~N})$ was applied as a recommended dose and a starter dose. Both calcium superphosphate and Ammonium nitrate were applied during soil preparation.

After 45 and 75 days from planting, the plants were uprooted and number and dry weight of nodules/plant were determined. Plant shoots were 
dried at $70^{\circ} \mathrm{C}$ for $72 \mathrm{~h}$., weighed, milled and analyzed for nitrogen percentage by semi- microkjeldahl procedure according to piper (1950).

\section{Disease assessment:}

Root rot was assessed on the basis of percent of seedling emergence and infection percentage. Percentage of seedling emergence was recorded after germination while infection percentage of infected faba bean roots with Rhizoctonia solani and Fusarium solani were recoded after 45 and 75 days from planting. Statistical analysis of collected data was done according to Snedecor and Cochran (1980).

\section{RESULTS AND DISCUSSION}

Effect of soil treated with copper oxychloride and sulphur on faba bean plants infected with Rhizoctonia solani and Fusarium solani

\section{1- Seedling emergence}

Data in Table (2) show that the soil infected with Rhizoctonia solani, scored the lowest seedling emergence among all treatments. Application of the fungicides alone or in combination with Rhizobium inoculation increased seedling emergence compared with control plants. On the other hand, infection of faba bean with Fusarium showed lower emergence compared to soil infested with Rhizoctonia. Rhizobium inoculation in soil infected with Fusarium had no effect on seedling emergence compared to control. Application of fungicides reduced seedling emergence compared to control treatment. These results indicated that using copper oxychloride or sulphur as fungicides for controlling faba bean root rot caused by Fusarium solani had negative effect on seedling emergence. However, Rhizobium inoculation combined with copper oxychloride showed higher emergence compared to those treated with copper oxychloride alone. These results are in agreement with those obtained by Muthomi et al. (2007). They stated that Rhizoctonia significantly reduced seedling emergence in legumes and application of copper oxychloride as a fungicide decreased significantly seedling mortality in Rhizoctonia treated seeds but the fungicide had little effect on Fusarium.

Table (2): Seedling emergence \% of faba bean treated with fungicides and infected with the pathogens

\begin{tabular}{|l|c|c|c|}
\hline \multicolumn{1}{|c|}{ Treatment } & $\begin{array}{c}\text { Soil infected with } \\
\text { Rhizoctonia }\end{array}$ & $\begin{array}{c}\text { Soil infected with } \\
\text { Fusarium }\end{array}$ & Non-infected soil \\
\hline Control & 52.50 & 62.50 & 93.75 \\
\hline Sulphur(S) & 87.50 & 31.25 & 100.0 \\
\hline Copper oxychloride(Cu) & 93.70 & 50.00 & 100.0 \\
\hline Rhizobium inoculation (R) & 75.00 & 62.50 & 93.75 \\
\hline S+R & 81.25 & 50.00 & 87.50 \\
\hline Cu+R & 81.25 & 62.50 & 93.75 \\
\hline
\end{tabular}

\section{2- Infection percentage}

Data presented in Table (3) show that the soil infected with Rhizoctonia solani (control treatment) scored the highest percentage of infection after 45 and 75 days from planting compared to all other treatments. Inoculation with Rhizobium decreased significantly infection \% in both periods. Soil treated 
with copper oxychloride or sulphur also decreased significantly infection \% compared to control. Combination of sulphur with Rhizobium inoculation showed less protection against Rhizoctonia solani compared to soil treated with sulphur only. The most effective treatment in reducing infection \% caused by Rhizoctonia solani was recorded in soil treated with copper oxychloride or sulphur. These results are in agreement with those obtained by Muthomi et al. (2007).

Regarding to the effect of copper oxychloride and sulphur on faba bean plants infected with Fusarium solani, inoculation with Rhizobium decreased infection $\%$ in both periods. Soil treated with sulphur also decreased infection $\%$ compared to control. On the other hand, application of copper oxychloride or combination of Rhizobium and copper oxychloride had no effect on the infection \% with Fusarium solani after 75 days from planting.

It could be concluded from these results that Rhizobium inoculation plays an important role in reducing the infection \% of the fungal pathogens. These results are in agreement with those reported by Dileep Kumar et al. (2001). They found that some strains of Rhizobium leguminosarum bv.v icea produce siderophores and other compounds and may be involved in the mechanism of antagonism. Also, in a study of using Rhizobium species against various soil pathogens, Buonassisi et al. (1986) determined that some Rhizobium species isolated from bean inhibited Fusarium species. Chao (1990) and Ozkoc et al. (2001) demonstrated that Rhizobium leguminosarum biovar phaseoli was variably effective on the inhibition of Fusarium. Muthomi et al. (2007) investigate the effect of copper oxychloride as a seed dresser on legume root rot pathogens. They found that the fungicide seed dressing significantly increased seedling emergence and reduced seedling mortality. They found that Rhizoctonia solani and Sclerotinia sclerotiorum were more pathogenic and significantly increased seedling mortality and greatly reduced seedling emergence. Al-Kahal et al. (2003) found that inoculation of faba bean with Rhizobium leguminosarum and Bradyrhizobium japonicum as a plant growth promoting rhizpbacteria was significant for reducing faba bean root disease caused by Fusarium oxysporum under greenhouse conditions.

Table (3) Effect of copper oxychloride and sulphur on faba bean infection percentage

\begin{tabular}{|l|c|c|c|c|}
\hline \multirow{2}{*}{ Treatment } & \multicolumn{2}{c|}{ Infected soil with Rhizoctonia } & \multicolumn{2}{c|}{ Infected soil with Fusarium } \\
\cline { 2 - 5 } & After 45 days & After 75 days & After 45 days & After 75 days \\
\hline Control & 62.5 & 62.5 & 62.8 & 57.0 \\
\hline Sulphur(S) & 25.0 & 37.6 & 37.5 & 50.0 \\
\hline Copper oxychloride(Cu) & 25.0 & 37.5 & 62.5 & 62.5 \\
\hline Rhizobium inoculation (R) & 37.5 & 50.0 & 25.0 & 50.0 \\
\hline S+R & 37.5 & 50.0 & 62.5 & 75.0 \\
\hline Cu+R & 25.0 & 50.0 & 50.0 & 62.5 \\
\hline L.S.D. at 5\% & 10.00 & 12.54 & 23.65 & 9.34 \\
\hline
\end{tabular}

\section{3- Nodulation of faba bean}

Results in Table (4) show that after 45 days from planting, there was a significant increase in number and dry weight of nodules in plants inoculated with Rhizobium compared to control ones (plants infected with Rhizoctonia 
only). Muthomi et al. (2007) found that inoculation with Rhizobium improved nodulation in soil infected with Rhizoctonia. Combination of Rhizobium and the fungicides also increased significantly number of nodules, but there was a decrease in dry weight of nodules. After 75 days, there was a decrease in number of nodules in all treatments compared to control plants. However, application of the fungicides separately or in combination with Rhizobium increased dry weight of nodules. These results revealed that application of copper oxychloride or sulphur with or without Rhizobium inoculation had no effect on nodulation status in infected faba bean plants with Rhizoctonia solani. Concerning to the effect of Fusarium solani on nodulation status after 45 days, data in Table (4) showed that plants inoculated with Rhizobium scorded the highest number and dry weight of nodules compared to all other treatments. There was a significant increase in number and dry weight of nodules in plants inoculated with Rhizobium compared with control ones (plants infected with Rhizoctonia only). Al-Kahal et al. (2003) found that inoculation of faba bean with Rhizobium leguminosarum and Bradyrhizobium japonicum as a plant growth promoting rhizpbacteria increased significantly number and dry weight of nodules and shoots dry weight of infested and non infested plants under greenhouse conditions. The same trend was also observed in plants infested with Rhizoctonia solani and inoculated with Rhizobium. Application of Rhizobium combined with the fungicides had no effect on nodulation. Application of the fungicide copper oxychloride or sulphur combined with Rhizobium had negative effect on nodulation status compared to control. In the second period, in spite of application of Rhizobium or combination of bacterial inoculum besides the fungicides inceased number of nodules, but there was a reduction in dry weight of nodules. This result indicates that Fusarium, which cause root rot disease, had an inhibitory effect on the nodulation of faba bean even in the presence of the fungicides.

Table (4): Nodulation status of infected faba bean plants as affected by application of the fungicides and Rhizobium inoculation

\begin{tabular}{|c|c|c|c|c|c|c|c|c|}
\hline \multirow{3}{*}{ 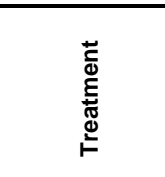 } & \multicolumn{4}{|c|}{ Soil Infected with Rhizoctonia } & \multicolumn{4}{|c|}{ Soil Infected with Fusarium } \\
\hline & \multicolumn{2}{|c|}{ After 45 days } & \multicolumn{2}{|c|}{ After 75 days } & \multicolumn{2}{|c|}{ After 45 days } & \multicolumn{2}{|c|}{ After 75 days } \\
\hline & $\begin{array}{c}\text { No. } \\
\text { nodules } \\
\text { /plant }\end{array}$ & $\begin{array}{c}\text { Dry wt. } \\
\text { nodules } \\
\text { /plant }(\mathbf{m g})\end{array}$ & $\begin{array}{c}\text { No. } \\
\text { nodules } \\
\text { /plant }\end{array}$ & $\begin{array}{c}\text { Dry wt. } \\
\text { nodules/ } \\
\text { plant (mg) }\end{array}$ & $\begin{array}{c}\text { No. } \\
\text { nodules } \\
\text { /plant }\end{array}$ & $\begin{array}{c}\text { Dry wt. } \\
\text { nodules } \\
\text { /plant (mg) }\end{array}$ & $\begin{array}{c}\text { No. } \\
\text { nodules } \\
\text { /plant }\end{array}$ & $\begin{array}{c}\text { Dry wt. } \\
\text { nodules } \\
\text { /plant(mg) }\end{array}$ \\
\hline Control & 12 & 0.047 & 62 & 0.023 & 19 & 0.023 & 43.5 & 0.09 \\
\hline Sulphur(S) & 11 & 0.02 & 17.5 & 0.07 & 32.5 & 0.032 & 26.66 & 0.065 \\
\hline $\begin{array}{l}\text { Copper } \\
\text { oxychloride } \\
\text { (Cu) }\end{array}$ & 16.25 & 0.022 & 48 & 0.11 & 12.5 & 0.013 & 40 & 0.068 \\
\hline $\begin{array}{l}\text { Rhizobium } \\
\text { inoculation (R) }\end{array}$ & 30.66 & 0.36 & 50.23 & 0.07 & 89.25 & 0.078 & 66.5 & 0.06 \\
\hline $\mathrm{S}+\mathrm{R}$ & 41.83 & 0.032 & 54.5 & 0.08 & 15.67 & 0.015 & 67.25 & 0.067 \\
\hline $\mathrm{Cu}+\mathrm{R}$ & 21.5 & 0.022 & 36.25 & 0.09 & 13 & 0.048 & 63.75 & 0.22 \\
\hline L.S.D.at $5 \%$ & 13.67 & 0.042 & 24.53 & 0.06 & 23.88 & 0.026 & 13.65 & 0.19 \\
\hline
\end{tabular}




\section{4- Faba bean shoots dry weight}

Data presented in Table (5) show that soil infected with Rhizoctonia solani (control) scored the lowest dry weight of shoots compared to all other treatments after 45 days from planting. There was no significant difference was recorded in soil treated with the fungicides and control treatment. Rhizobium inoculation scored the highest dry weight of shoots among all treatments. Muthomi et al. (2007) found that Rhizobium inoculation improved shoot dry weight of legumes in soil infected with Rhizoctonia. After 75 days from planting, there was a significant increase in dry weight of shoots in soil treated with Copper oxychloride compared to control plants. Rhizobium inoculation also increased significantly dry weight of faba bean shoots. It could be concluded from these results that Rhizobium inoculation had an inhibitory effect on the pathogen Rhizoctonia solani as indicated in both periods. Copper oxychloride or sulphur decreased the infection caused by the pathogen and in turn, increased shoots dry weight. Plants treated with copper oxychloride or sulphur scored the highest value of $\mathrm{N}$-percentage.

Data in Table (5) reveal that plants infested with Fusarium solani scored the lowest dry weight of shoots and $\mathrm{N}-\%$ among all treatments; however, there was a significant difference in dry weight of shoots after 45 days from planting in plants inoculated with Rhizobium only and control ones. Combination of Rhizobium inoculation and application of the fungicides gave an increase in dry weight of shoots but not significant compared to control. On the other hand, after 75 days, there was non-significant difference in all treatment. These results indicate that Fusarium solani was more pathogenic than Rhizoctonia solani in terms of its negative effect on dry weight of faba bean shoots.

Table (5) Dry weight of infected faba bean plants as affected by application of the fungicides and Rhizobium inoculation

\begin{tabular}{|c|c|c|c|c|c|c|c|c|}
\hline \multirow{3}{*}{ 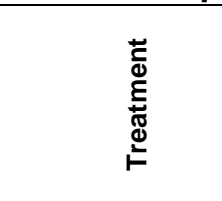 } & \multicolumn{4}{|c|}{ Infested soil with Rhizoctonia } & \multicolumn{4}{|c|}{ Infested Soil with Fusariumm } \\
\hline & \multicolumn{2}{|c|}{ After 45 day } & \multicolumn{2}{|c|}{ After 75 day } & \multicolumn{2}{|c|}{ After 45 day } & \multicolumn{2}{|c|}{ After 75 day } \\
\hline & $\begin{array}{c}\text { Dry wt. } \\
\text { shoots } \\
\text { /plant } \\
\text { (g) }\end{array}$ & $\mathrm{N}-\%$ & $\begin{array}{c}\text { Dry wt. } \\
\text { shoots } \\
\text { /plant } \\
\text { (g }\end{array}$ & $\begin{array}{l}\mathrm{N}- \\
\%\end{array}$ & $\begin{array}{c}\text { Dry wt. } \\
\text { shoots } \\
\text { /plant } \\
\text { (g) }\end{array}$ & $\mathrm{N}-\%$ & $\begin{array}{c}\text { Dry wt. } \\
\text { shoots } \\
\text { /plant } \\
\text { (g) }\end{array}$ & $\begin{array}{l}\mathrm{N}- \\
\%\end{array}$ \\
\hline Control & 0.50 & 4.8 & 1.850 & 2.7 & 1.01 & 6.2 & 4.30 & 6.1 \\
\hline Sulphur(S) & 0.96 & 5.6 & 1.113 & 3.4 & 1.12 & 4.7 & 3.62 & 4.1 \\
\hline $\begin{array}{l}\text { Copper } \\
\text { oxychloride (Cu) }\end{array}$ & 0.90 & 5.6 & 3.33 & 4.6 & 1.24 & 2.5 & 2.78 & 4.7 \\
\hline $\begin{array}{l}\text { Rhizobium } \\
\text { inoculation }(\mathrm{R})\end{array}$ & 1.177 & 3.4 & 3.16 & 3.8 & 1.97 & 5.3 & 3.33 & 5.1 \\
\hline $\mathrm{S}+\mathrm{R}$ & 0.93 & 4.1 & 1.910 & 4.9 & 1.20 & 5.1 & 4.56 & 2.9 \\
\hline $\mathrm{Cu}+\mathrm{R}$ & 1.043 & 3.9 & 2.70 & 2.9 & 1.33 & 3.9 & 3.76 & 4.1 \\
\hline L.S.D.at $5 \%$ & 0.49 & -- & 0.90 & -- & 0.338 & -- & 0.93 & -- \\
\hline
\end{tabular}




\section{REFERENCES}

Al-Kahal, A. A.; A.A. Ragab; S.A. Saieda and S.A. Omar (2003). Use of plant growth promoting rhizobacteria for controlling faba bean roots disease caused by Fusarium oxysporum. Eleventh Conference of Microbiology; Cairo; Egypt; Oct. 12-14.

Buonassisi, A.J.; R.J. Copeman; H.S. Pepin and G.W. Eaton (1986). Effect of Rhizobium spp. on Fusarium oxysporum F.Sp phseoli. Can. J. Pathol.,8: 140-146.

Chao, W. L. (1990). Antagonistic activity of Rhizobium spp. against beneficial and plant pathogenic fungi. Lett. Appl. Microbiol. 10: 213-215.

Curley, R.L. and J.C. Burton ( 1975). Compatibility of Rhizobium japonisum with chemical seed treatments. Agron. J., 67: 807-808.

Dileep Kumar, B.S.; I. Berygrenn and A.M. Martensson (2001). Potential for improving pea production by co-inoculation with fluorscent Pseudomonas and Rhizobium. Plant and soil 22(a): 25-34.

Mapper, D.; W. Porreye and T. Deckers (1984). Trial results with a new copper formulation for the control of fire blight. Acta. Hortic V.151, PP: 173-177.

Muthomi, J. W.; P.E. Otieno; G.N. Chemining,wa; J. H. Nderitu and J. M. Wagacha (2007). Effect of legume root rot pathogens and fungicide seed treatment on nodulation and biomass accumulation. J. Biological Sciences 7: 1163-1170.

Ozkoc, I.; Muhammet, and H. Deliveli (2001). In vitro inhibition of the mycelial growth of some root rot fungi by Rhizobium leguminsarum biovar phaseoli isolates. Turk. J.Biol.25: 435-445.

Piper, C.S. (1950). Soil and Plant Analysis. First edition. Interscience Publishers, Y.Y.

Revellin, C., P. Leterme and G. Catroux (1993). Effect of some fungicide seed treatment on the survival of Bradyrhizobium japonicum and on the nodulation and yield of soybean (Glycine max L. Merr) Biol. Fert. Soils, 16: 211-214.

Roughley, R.S.; J.T. Sprent and J.M. Day (1983). Nitrogen fixation. Cited in the faba bean.Ed. P.D. Hebblethwaite, Pub., Butterworths, pp: 233260.

Salt, G.A. (1983) Root diseases of Vicia faba L., cited in the faba bean, Ed., P.D., Hebblethwaite, Pub., Butterworths, pp: 393-419.

Snedecor, G.W. and W.G. Cochran (1981). Statistical Methods, $6^{\text {th }}$ Editin, lowa State Univ. Press, Ames, lowa, USA.

U.S. Environmental Protection Agency. May (1991). Registeration Eligibility Document Facts: Sulfur. US EPA, Office of Pesticide Programs, Washington, DC. 


\section{تأثير إضافة أكسي كلورو النحاس والكبريت المعدني والتلقيح بالريزوبيا علي مرض أعفان الجذور وعلي العقد الجذرية ونمو نبات الفول البلدي

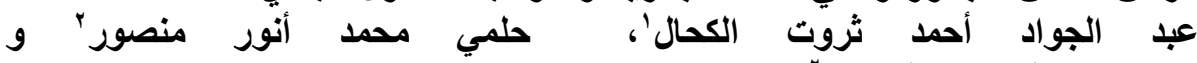

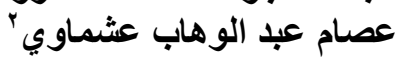

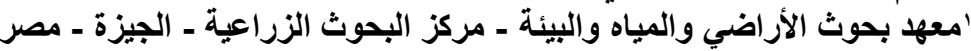

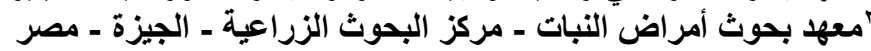

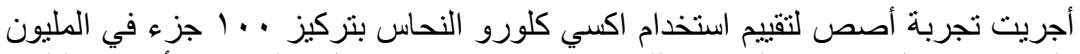

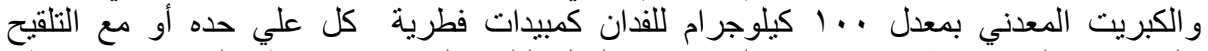

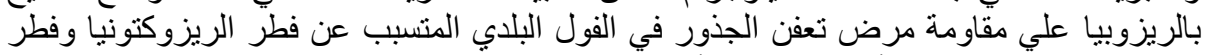

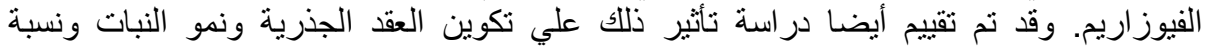
النتروجين به. وكانت النتائج كالأتي:

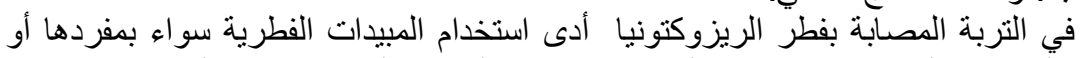

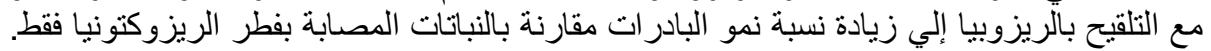

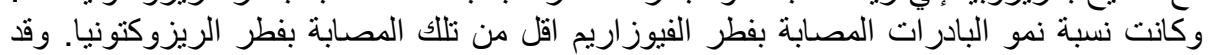

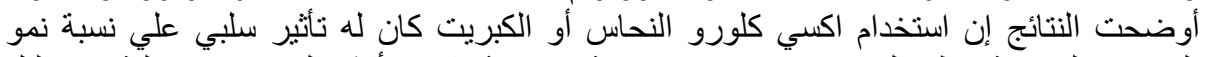

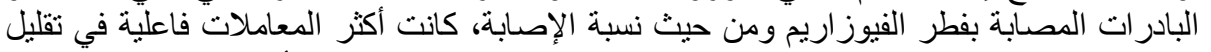

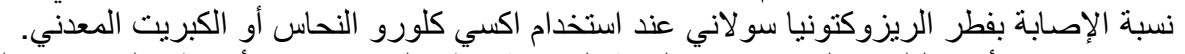

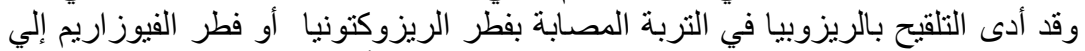

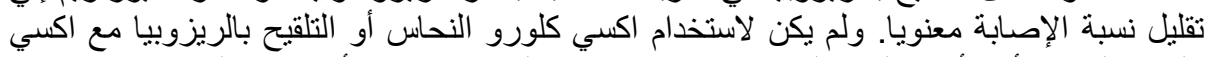

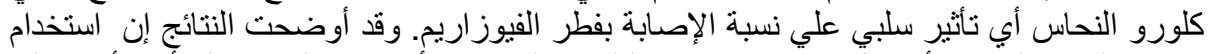

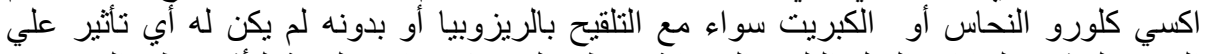

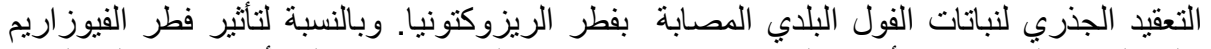

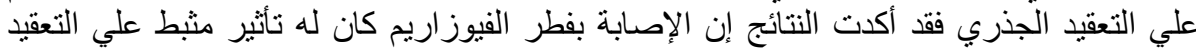
الجذري لنباتات الفول البلاي حني في وجود المبيدات البات الفطرية.

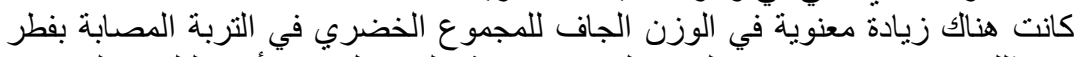

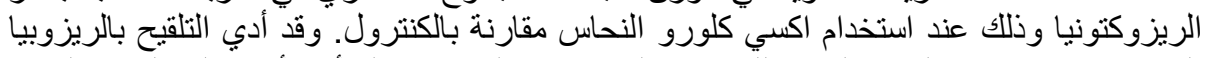

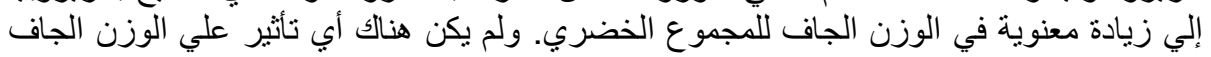

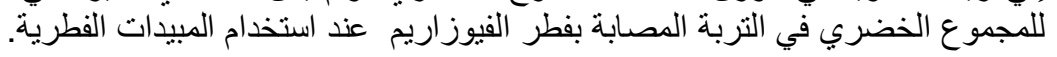

